\title{
Exílio e diáspora nas personagens de ficção Paulo Martins (Terra em transe) e Paco (Terra estrangeira)
}

\author{
Exile and diaspora in the fictional film characters \\ of Paulo Martins (Terra em transe) and \\ Paco (Terra estrangeira)
}

\author{
Paulo Marcondes Ferreira Soares*
}

\begin{abstract}
Resumo: O estudo centra-se em aspectos dados às configurações das personagens Paulo Martins, do filme Terra em transe (Glauber Rocha, 1967), e Paco, do filme Terra estrangeira (Walter Salles e Daniela Thomas, 1996), relativamente às dimensões identitárias, políticas e de contextualidade (tempo diegético e espaço diegético) vividas por essas personagens na sociedade interna dos filmes vis a vis às dimensões culturais $\mathrm{e}$ identitárias, mas, também, políticas e contextuais em que tais películas foram produzidas. Não se trata de traçar um perfil psicológico das personagens, mas de refletir o que as leva, e em que circunstâncias, a assumir determinadas atitudes frente ao impasse em que se encontram e de como suas atitudes, apesar de estarem relacionadas a situações históricas distintas, são construções ficcionais que se ligam a processos identitários que remetem a um sentido de lugar. O ponto que move meu argumento está numa passagem de um texto do crítico Paulo Emílio Salles Gomes, sobre A personagem cinematográfica, em que diz: "Fundamentalmente arte de personagens e situações que se projetam no tempo". E eu acrescentaria: no espaço. Nesse texto, Gomes inicia uma discussão sobre o problema da autonomia no cinema, um debate fervoroso que historicamente opôs teóricos formalistas e realistas. No que pese às alegorias a propósito de um lugar de origem, bem como a amarga situação vivida pela derrota política nas histórias ficcionais desses filmes, eles operam a partir de referentes miméticos que coincidem em termos de estrutura fílmica, mas, distinguem-se em termos das possibilidades políticas encontradas pelas suas personagens em face de uma tomada de decisão. Ao passo que Paulo Martins se volta para o enfrentamento em defesa de um projeto político de nação, Paco parte para o exílio, lançado numa diáspora, sem quaisquer projetos políticos e sem o vislumbre de um lugar. Ante a possibilidade de ser confinado a um exílio interno, Paulo Martins se
\end{abstract}

* Doutor em Sociologia pela Universidade Federal de Pernambuco e professor do Departamento de Sociologia e do PPG em Sociologia da Universidade Federal de Pernambuco, em Recife, PE $<$ paulomfsoares@gmail.com>.

\begin{tabular}{|l|l|l|l|l|l|}
\hline Civitas & Porto Alegre & v. 14 & n. 1 & p. 93-125 & jan.-abr. 2014 \\
\hline
\end{tabular}


lança numa rota suicida de enfrentamento; por sua vez, Paco se vê lançado num exílio externo e numa situação à deriva, por absoluta falta de condições materiais e emocionais de permanência no lugar, em direção a uma existência regida pelo signo da instabilidade e da morte, mas, em busca de suas origens ancestrais. Numa situação, a personagem é compelida ao enfrentamento; na outra, à fuga.

Palavras-chaves: Cinema nacional. Cinema e política. Personagens de ficção. Exílio e diáspora.

Abstract: The study is based on aspects attributed to the make-up of the characters of Paulo Martins, in the film Terra em transe [Entranced earth; Anguished land] (Glauber Rocha, 1967), and Paco, in the film Terra estrangeira [Foreign land] (Walter Salles and Daniela Thomas, 1996), with respect to the dimensions of identity, politics and of context (narrative time and space) experienced by these personages in the internal society of these films vis a vis the cultural and identity dimensions, as well as the politics and context in which these films were produced. This is not a study of the psychological profile of the personages, but a reflection on what, and under what circumstances, caused them assume specific attitudes, faced with the impasse of their situation; and how these attitudes, although related to distinct historical situations, are fictional constructions that bind the identity process to a reflection of the sense of place. My argument is informed by a passage from a text of the critic Pablo Emilio Salles Gomes, on the cinematographic personage, where he says: "Basically the art of personages and situations is how they project in time". And, I would add: in space. In this text, Gomes initiates a discussion of the problem of autonomy in cinema, which is under debate that has historically opposed formalists and realists. In spite of the allegories about a place of origin, as well as the bitter situation experienced as a result of political defeat in the fictional stories of these films, they are both based on mimetic referents which coincide in terms of the filmatic structure, but are different in terms of the political possibilities encountered by their characters in the face of having to make a decision. To the point that Pablo Martins returns to face the defense of a national political project while Paco goes into exile, on a journey, without any political projects and without a sense of place. With the possibility of being confined to an internal exile, Pablo Martins sets out on a suicidal road of confrontation; in contrast, Paco goes for external exile, and is set adrift, for absolute lack of material and emotional conditions to stay in one place, towards an existence governed by signs of instability and death, in search of his ancestral origins. In the one situation, the personage is compelled to confrontation; in the other, to escape.

Keywords: National cinema. Cinema and politics. Fictional personages. Exile and diaspora.

\section{Introdução}

A ideia deste ensaio surgiu de minhas reflexões sobre questões de identidade manifestas nas produções cinematográficas do Brasil e de outros países das Américas Central e do Sul, nos anos 1960, e que denominei, noutro momento (Soares, 2009), de "um cinema à margem". Embora distintas em suas realizações tanto formais quanto políticas, essas produções estavam marcadas, em contrapartida, por ideologias e políticas culturais que as faziam confluir para o que se poderia caracterizar nos termos de um cinema autóctone, 
em diálogo e em oposição ao que pudesse ser identificado como um cinema hegemônico: não somente o da América do Norte, mas, também, os cinemas da Europa e da União Soviética.

Pode-se dizer que o ideário fanoniano da "descolonização da mente" se mostrava como o principal ponto de consonância relativamente à construção de uma cinematografia própria, da região, ainda que distinta entre si. Concorriam para isso, transformações enredadas no contexto político do pósguerra, sobretudo, no chamado Terceiro Mundo: palco de revoluções e de lutas de libertação nacional nos continentes americano, africano e asiático, mas, também, de um forte nacionalismo populista de esquerda no sul e de experiências traumáticas e antidemocráticas promovidas pelo autoritarismo político e por sucessivos golpes de estado na região. Nesse cenário, a afirmação de um cinema nacional só poderia se dar a partir de uma posição anticolonialista radical, confirmada tanto na produção de filmes quanto na elaboração de manifestos programáticos com vistas à fundação de uma estética cinematográfica própria.

Ao identificar a posição anticolonialista nessa produção dos anos de 1960, o faço por nela perceber, não especificamente a persecução de um discurso híbrido que enseje um lugar de fala, num sentido pós-colonial, mas um princípio de construção de identidade de cunho dualista, do tipo nacional vs. estrangeiro - ainda que esse procedimento não se dê, necessariamente, por uma visão essencializadora do nacional. Em vez disso, a referência ao lugar se funda em premissas históricas de explicação das formas de dominação e do consequente subdesenvolvimento da região. Ou melhor, do mundo subdesenvolvido. Tanto que, em vária medida, as alegorias do nacional, mesmo quando referidas a um país, manifestam-se como narrativas que tomam a abrangência de um terceiro-mundismo. Por sua vez, categorias conceituais como "colonizador-colonizado" (Albert Memmi, 1978), "ocupante-ocupado" (Paulo Emílio Salles Gomes, 1986), "Terceiro Cinema” (Fernando Solanas e Octavio Getino, [1969]) e "Estética da Fome" (Glauber Rocha, 1981[1965]), por exemplo, se dão numa mesma conotação e abrangência.

Diferentemente desse quadro geral, um olhar sobre a produção cinematográfica recente, em contextos de globalização, nos remete necessariamente a novas configurações conceituais pertinentes aos campos de força de construção de identidades do presente - consubstanciados em teses sobre a sua condição de identidade discursiva num entre lugar, num hibridismo, numa diáspora. Mas, também, com respeito a categorias como gênero, raça e etnicidades, e não tanto com relação a categorias mais tradicionais de classes sociais. Com efeito, novas abordagens do cinema têm procurado privilegiar o debate em torno da 
ideia do transnacional ou de uma inter/transculturalidade; ou de estéticas do hibridismo, para além do terceiro cinema; ou de um cinema com sotaque ou da diáspora.

O passeio rápido e generalista desta exposição se deve ao fato de querer situar dois momentos históricos específicos da produção cinematográfica desde o pós-guerra, de modo a justificar a problemática que me interessa aqui discutir: não as características supostamente dominantes em dois momentos da produção cinematográfica brasileira e/ou periférica de um modo geral; mas a possibilidade de uma aplicação dos conceitos de exílio e diáspora relativamente às configurações dadas a duas personagens manifestas no cinema brasileiro, em dois filmes bem representativos, estético-politicamente, das tensões envolvidas na construção de identidades considerando-se o princípio de autonomia do filme vis a vis sua dialógica com o tempo e contexto em que se produz.

\section{Um foco nas personagens}

As personagens em foco são Paulo Martins, do filme Terra em transe (1967), de Glauber Rocha, e Paco, do filme Terra estrangeira (1996), de Walter Salles e Daniela Thomas. O ponto central é a caracterização das personagens no tocante ao impasse político em que se encontram nas tramas dos respectivos filmes, e a saída que encontram para esses impasses. Deste ponto mais imediato, somos levados a caracterizar as atitudes dessas personagens em termos de um enfrentamento da situação de impasse em Paulo Martins e de fuga em Paco.

As tramas ficcionais dos filmes em evidência narram, de uma perspectiva mais alegórica ou mais documental e jornalística, situações que as ligam dialogicamente a dois momentos emblemáticos da realidade política brasileira: a referência ao golpe de 1964, pelos militares (e aqui se inscreve, também, a referência a uma tradição autoritária da América Latina) - é o caso do filme Terra em transe; de outro lado, a referência ao estado de redemocratização do país, quando da eleição do primeiro presidente civil eleito pela maioria - é o caso de Terra estrangeira, que inicia seu enredo quase que jornalisticamente narrando o episódio do confisco da poupança pela política econômica do então empossado presidente Collor.

Neste ponto, ressalto que não irei traçar quadros paralelos entre os eventos reais supramencionados e os episódios dos filmes. Por considerar que tais eventos nos são ainda recentes e bastante discutidos e dados os limites deste ensaio, pretendo lidar especificamente com a trama cinematográfica e a situação de suas personagens nela. Dessa estratégia, contudo, referências àqueles momentos históricos surgirão, visto que este ensaio parte do 
pressuposto de que, na cinematografia em questão, fatores estéticos (referidos ao campo da linguagem) e extraestéticos (ao amplo campo da identidade, violência, miséria material e sociopolítica) compõem a matéria interna dos filmes, seu tempo e espaço diegético (Núñez, 2006, p. 61).

O filme Terra em transe (Rocha, 1967/2006) se inicia com a renúncia de Filipe Vieira, governador de Alecrim, província de El Dourado, lendário país incrustado nas Américas. Interessante notar como a ambivalência épica do filme, sua narrativa, sua alegoria de um lugar, opta justamente pela aproximação e pelo distanciamento em face da possibilidade de uma identificação imediata para com um ou outro lugar específico. Tanto que dentre os propósitos do diretor encontra-se o jogo estético da quebra de identificação da sociedade interna do filme para com lugares e personagens da nossa história. A recusa do uso da luz artificial e o uso de imagens estouradas em determinadas cenas corroboram para o apagamento de sinais evidenciadores de locais públicos; por outro lado, a atribuição de nomes em português e em espanhol aos personagens, alguns dos quais retirados da história política latino-americana, e recontextualizados, endossam o processo de recriação de uma geopolítica do filme aparentemente posta sob o signo de um pan-americanismo.

Como assinala Glauber, em depoimento que consta no documentário Depois do transe (Rocha e Pizzini, 2006), o filme está “ambientado no México, na América Latina". E continua:

é a história do Jango, do Arraes e do Lacerda. O estado do janguismo no Brasil, com a própria América Latina, mostrando o ódio pela colonização, a luta de classes, o racismo, o subdesenvolvimento, o marginalismo. Desmistificando o povo, desidealizando o proletariado, que é justamente romantizado pelo Romantismo e pelo socialismo; e pelos europeus, porque evidentemente, o nível do proletariado europeu é superior ao da América Latina, mais culto, sabe ler, sabe escrever (Rocha in Rocha e Pizzini, 2006).

Como sinopse do filme, podemos dizer que trata da renúncia de Filipe Vieira, um governante populista de esquerda, mas eleito pelo povo, através de um golpe de estado promovido pelas forças de direita, representadas pela figura de Porfírio Diaz. No processo da trama, que leva a tal desfecho, o empresário nacionalista de esquerda Julio Fuentes deixa de apoiar Vieira para ficar ao lado de Porfírio Diaz, em troca de acordos econômicos com a Explint, empresa multinacional que ameaça esmagá-lo caso ele se mantenha na posição nacionalista. No trânsito dessas personagens encontra-se Paulo Martins, poeta e jornalista que, aparentemente, é iniciado na política por Porfírio Diaz, senador cuja trajetória vai do anarquismo juvenil ao conservadorismo político. 
Em apoio a Sara, militante de esquerda que apoia Vieira, Paulo rompe com Diaz e elege Vieira governador de Alecrim. As contradições entre as promessas do candidato e as ações do governante, e seus compromissos com o capital, gera um conjunto de tensões e uma séria crise de governabilidade junto às massas camponesas. Desse impasse e frente à renúncia de Vieira, Paulo parte para o confronto armado contra as forças golpistas, ao quebrar um bloqueio policial, sendo ferido de morte. Esta é a cena inicial do filme, que é cortada para narrar a trajetória do próprio Paulo Martins e suas ligações com Diaz, Vieira e Fuentes.

O filme Terra estrangeira (Salles e Thomas, 1996) encontra-se ambientado no Brasil e em Portugal, tendo como trama inicial a situação de desamparo vivida pelo jovem Paco, filho único de Manuela, uma espanhola da região de San Sebastian que economizou dinheiro na poupança para garantir a planejada viagem com Paco à sua cidade natal. O desejo de Manuela é tal, que numa cena do filme ela senta com ele no sofá e fala de uma agência que oferece planos de viagem com prestações a juros baixos, de modo a complementar o que ela havia economizado na poupança. Paco reage e diz que deveriam adiar a viagem, por não terem condições financeiras de viajar naquele momento, e se manter por lá. E Manuela diz:

Você não entende. Você pode dizer 'esquece San Sebastian', como se fosse um capricho meu. É San Sebastian que não me larga, Paco. [...] Eu ando pela casa e sinto um cheiro, um cheiro antigo. Eu sei que não é possível, mas eu sinto. Eu tenho que voltar lá pra acabar com essa agonia. Será que não dá pra entender isso? Será que não dá para entender? (Salles e Thomas, 1996).

Manuela, contudo, vê seu sonho se desfazer, quando do confisco da poupança, promovido pelo então presidente Fernando Collor de Mello, episódio no filme relacionado, como sabemos, ao caso real do confisco da poupança, levado a efeito a partir do que ficou conhecido como Plano Collor de contenção da inflação e estabilização da moeda, que foi convertida de Cruzado Novo para Cruzeiro.

No filme, ao assistir o pronunciamento da então ministra da economia, Zélia Cardoso, que explica o que rege a medida do Plano do Governo recémempossado, e consciente de que seu dinheiro na poupança ficaria "congelado", Manuela tem um infarto e morre, frustrada ante a impossibilidade de viabilizar seu sonho e sob forte impacto emocional.

Paco vê-se em completo desamparo e aceita a proposta de um desconhecido, Igor, um português que mora em São Paulo e é dono de um 
antiquário, de transportar um violino para Portugal, numa ação aparentemente legal e que lhe garantiria, com o pé na Europa, realizar o tão almejado sonho da mãe. Paco não se dá conta de que transporta contrabando de pedras preciosas. Uma vez em Portugal, tem o violino misteriosamente roubado no hotel em que fica hospedado - aí conhece migrantes advindos de países africanos de colonização portuguesa, mas, também, Alex, uma brasileira que perde o companheiro Miguel, também brasileiro, assassinado por envolvimento em atividades ilícitas, com o contrabando, e por dar calote aos seus fornecedores. Miguel era o contato a quem Paco deveria entregar o violino.

À procura de Miguel, Paco o vê ser levado morto e fica com um cartão que cai nas escadarias, enquanto Miguel é levado. O cartão é da livraria de Pedro, português amigo de Miguel e Alex, mas, também, amigo de Igor. No cartão, consta o nome dela. Paco vai à busca de Alex, que está muito mal com a morte do companheiro e o recebe de um modo muito reativo. Da tensão inicial do contato dos dois, por exemplo, Alex diz a Paco que ele não tem ideia de onde está se metendo, findam por se enamorar. Paco descobre que o violino foi roubado por Alex e Pedro e entregue a um desconhecido, como uma forma de se vingar de Igor pela morte de Miguel. Por não poder realizar a entrega da encomenda aos receptores em Portugal, Paco passa a ser perseguido por estes e pelo mandante, Igor, que lhe entregou o produto no Brasil e que vem a Portugal para resolver o problema. Paco foge com Alex em direção à Espanha, com a ajuda de Pedro, que será torturado e aparentemente morto por Igor. O casal é alcançado na fronteira, quando estão num restaurante, e Paco será gravemente ferido no confronto e levado por Alex, que rompe a fronteira com a Espanha a toda velocidade.

As imagens finais são as do carro na estrada, em território espanhol, ao som de uma das músicas mais emblemáticas dos anos 1970, na interpretação de Gal Costa (Fa-Tal - Gal a todo vapor, 1972), identificada como uma espécie de símbolo contracultural na música brasileira pós-tropicalista: Vapor barato, de Jards Macalé e Waly Salomão. A música fala de alguém que decidiu abandonar tudo e por os pés-na-estrada. A aura contracultural está em várias passagens da canção, como destacam Severiano e Mello (2006):

Com um título alusivo aos vapores da Cannabis sativa que impregnavam os ares do Pier, e uma letra, segundo Waly, 'direta, frontal, oposta à tendência liricista e nebulosa que predominava, dizendo o que era possível naquele momento de desencanto', 'Vapor barato' dá uma ideia do estilo adotado pela dupla. Sobre essa letra ('Oh, sim, eu estou tão cansado/mas não pra dizer/que não acredito mais em você'), Macalé pôs uma melodia e logo 'Vapor barato' se 
tornaria o hino dos hippies (especialmente dos que frequentavam as Dunas $\left.^{1}\right)$, que era cantado com entusiasmo pelas plateias do show da Gal (Severiano e Mello, 2006, p. 179).

Com referência ao "desencanto", citado por Waly, talvez seja digno de nota a alusão ao desencanto com que Alex, no filme, encara a vida. Ainda que se dê noutro contexto, tanto o do filme quanto o do momento histórico nele referido. Como numa cena, numa encosta à beira mar em Portugal, Alex diz que ali é o ponto final da Europa e que os portugueses achavam que logo adiante seria o paraíso, e ao navegar, acabaram descobrindo o Brasil. E ela encerra a fala dizendo: "Coitados". Mas, noutro momento, quando da fuga, Alex diz que gostaria muito de voltar para casa. Paco pergunta a Alex onde fica a casa dela, numa menção ao fato de serem eles, agora, sem paradeiro. E ela responde: "pois é, nem sei mais onde é".

O filme se vale menos de elementos alegóricos e assume uma linguagem mais direta, quase documental. Corrobora para isso o uso da imagem em preto e branco, além de recursos tipicamente jornalísticos, como os conflitos da imigração brasileira em Portugal, inclusive, como no caso da migração de dentistas brasileiros para aquele país à época em que o filme é narrado. Em particular, dada à situação econômica e política vivida pelo Brasil naquele momento, período Sarney, como a hiperinflação e os graves problemas de ajuste fiscal nas contas do governo, que o levou a uma situação de quase ingovernabilidade, com os consequentes reflexos de desemprego e baixos salários para o mercado de trabalho.

O filme se compõe um cenário realista, para narrar a situação particular de Paco que, em todo caso, parece querer representar um quadro mais amplo da crise vivida pelo país naqueles tempos, visto que o ficcional no filme se impregna de modo contundente do momento histórico brasileiro e mundial, sendo Portugal uma das rotas de fuga e de esperança para muitos, que, à maneira do que se passa no filme, findam por amargar a experiência de ver suas utopias se converterem em pura distopia. Nesse contexto, após a experiência de políticos e intelectuais brasileiros condenados ao exílio (e à diáspora), promovido pela ditadura militar em duas décadas anteriores, era agora, no tempo do filme, o momento de uma nova categoria de sujeitos, a do cidadão comum, muitas vezes alheio às questões sociais e às lutas políticas travadas no país de então, se verem lançados ao exílio por questões de ordem econômica e profissional, numa nova diáspora.

Referência a um local em construção no Pier de Ipanema, onde Gal e Macalé se encontravam, e que passou a ser chamado de "Dunas da Gal" ou "Dunas do Barato". 


\section{Nota sobre a personagem cinematográfica}

Antes de dar seguimento à discussão das questões centrais envolvidas nas personagens em pauta neste ensaio, como já indicado, relacionadas às da experiência do exílio e da diáspora nas suas histórias de ficção, valhome de uma breve caracterização da personagem cinematográfica tal como desenvolvida por Gomes (1981). De imediato, chama a atenção, já nas primeiras linhas do texto, a menção que o autor faz ao cinema como "tributário de todas as linguagens, artísticas ou não" (Gomes, 1981, p. 105). Para ele, quando se trata da "arte de personagens", o cinema apresenta suas principais vinculações com o teatro e o romance. Tanto que, no seu modo de ver, uma história da arte deveria tratar o cinema a partir de dois temas: o seu débito para com o teatro e para com a literatura. Uma maneira de desvincular o cinema dessa limitação é estudá-lo não como "obra-de-arte", mas como "fenômeno": "não é na estética, mas na sociologia que refulge a originalidade do cinema como arte viva do século" (Gomes, 1981, 106).

Este é o ponto, aliás, de interesse em se discutir os sentidos da personagem de ficção cinematográfica, particularmente, face à densidade sociológica que lhe será atribuída por Gomes em suas conclusões. O recurso que faço a esse debate tem relação com as ressalvas já indicadas no resumo deste ensaio e ao longo do texto, de que, ainda que referidas a situações históricas específicas, as personagens em estudo são fundamentalmente ficcionais, estejam elas representadas numa linguagem alegórica ou jornalística. Nessa direção, mesmo que suas tramas estejam enredadas em episódios tão marcantes e traumáticos da História brasileira recente, ainda assim, devemos tomar essas personagens como obras de ficção, claro, mediadas que estão pela realidade que as envolve. Este, por certo, é o sentido que, em termos sociológicos e, particularmente, de uma sociologia da arte, deve nos orientar como fundamento primordial na concepção das relações arte e sociedade, face às tensões sistematicamente presentes no que se pode configurar em termos de obra-contexto.

Num retorno a Gomes, a definição do cinema como uma síntese (ou "simbiose") expressa na forma de um "teatro romanceado" (a encarnação das personagens pelos atores) ou de um "romance teatralizado" (a reflexão/ imagem pode ser repetida), não se faz sem uma advertência, por ele formulada, de que devemos reconhecer os limites que nos são impostos pela matéria cinematográfica, quando sobre ela debruçamos nossas reflexões. Advoga o autor que ao subordinar o cinema ao romance e ao teatro, o faz como recurso ideológico no sentido de libertar o filme "do Cinema com C maiúsculo, tão ao gosto da crítica corrente" (Gomes, 1981, p. 106). Nesse sentido, percebe 
que as reflexões sobre o cinema nos levarão a concluir que a sua "impotência estética" não é capaz de perturbar a sua "vitalidade" (Gomes, 1981, p. 106). Diz ele:

O terreno que nos ocupa é dominado por uma articulação dialética entre um sistema confuso de ideias, o cinema, e um conjunto confuso de fatos, os filmes; mas o segundo grupo sempre levará a melhor (Gomes, 1981, p. 106-107).

Existem muitos modos de tratamento das personagens no cinema. Aquelas em que as personagens assumem livremente suas ações, que Gomes caracteriza como uma fórmula "objetiva". Outras em que o narrador assume o "ponto de vista" das personagens. Há, também, situações em que as personagens são construídas apenas literariamente, embora predomine a modalidade das personagens sendo encarnadas por atores (Gomes, 1981, p. 110-111). Por fim, embora tanto no teatro quanto no cinema as personagens sejam encarnadas por atores, a relação com o público, entretanto, é distinta.

Um ponto identificado por Gomes é o de uma maior intimidade do público com a personagem cinematográfica do que com a teatral, visto que, ao contrário do teatro, onde as personagens sempre aparecem dos pés à cabeça; no cinema, essa experiência se aproxima mais da realidade, já que, como na realidade, ora veremos "o conjunto do corpo, ora o busto, ora só a cabeça, a boca, os olhos, ou um olho só", (Gomes, 1981, p. 112). Com efeito, essa característica mais convencional da relação do público com o cinema parece desencadear um mecanismo mais forte de identificação (Gomes, 1981, p. 112-113).

Por outro lado, ao contrário das personagens do teatro, encarnadas por pessoas/atores em suas encenações no palco, no cinema só disporemos do "registro de suas imagens e vozes" (Gomes, 1981, p. 113). Nesse caso, a maior ligação do público é para com a personagem do teatro do que com a do cinema, à medida que neste as ações de toda a trama já se encontram fixadas, ao passo que no teatro há sempre o risco do inesperado na encenação que o ator faz de uma personagem, o que leva a existir uma tensão maior entre o público e os interpretes do espetáculo. Neste caso, o teatro é que comunga algo com a realidade que o cinema não possui (Gomes, 1981, p. 113).

Há, portanto, clara distinção entre as personagens do teatro e do cinema. Como assegura Gomes, a encenação no teatro é sempre provisória relativamente ao texto teatral, ao passo que, no cinema, o roteiro não é mais que uma etapa 
subordinada ao momento de registro da personagem encarnada num ator. Disso resulta uma "profunda ambiguidade da personagem cinematográfica" (Gomes, 1981, p. 114): o fato de o ator, ao encarnar uma personagem, ser, ele próprio, transformado nesta personagem de ficção. Mesmo para um ator que nos seja bastante familiar, ele tende a ser "personagens de ficção para a imaginação coletiva, num contexto quase mitológico" (idem) - um de seus exemplos é o caso Greta Garbo, e eu acrescento, do mito que se constituiu em torno dela, de seu silêncio, de sua reclusão. E conclui: "Dentro da ordem de pensamento aqui expostos, podemos admitir que no teatro o ator passa e o personagem permanece, ao passo que no cinema sucede exatamente o inverso" (Gomes, 1981, p. 114-115).

Em todo caso, nos lembra o autor, visto que no cinema o ator se transforma na personagem de ficção que encarna, não é exatamente o ator que permanece, mas a personagem de ficção em que ele se torna. A razão disso se encontra nas muito poderosas "raízes sociológicas" das personagens de ficção, muito mais fortes que a "pura emanação dramática" (Gomes, 1981, p. 115).

\section{Exílio e diáspora em performance}

"Para os escritores é fácil escrever novelas no exílio, em Paris. Para os cineastas é necessário fazer filmes na América Latina.' (Glauber Rocha-Cartas ao Mundo, p. 292)

Da observação das personagens enunciadas neste trabalho, alguns sinais nos apontam para as questões adversas, por elas vivenciadas, a ponto de se verem impelidas à condição de vida na diáspora e no exílio, tal como se evidencia nas sinopses dos filmes em estudo. Mais particularmente, pensei na condição do exílio a partir de duas referências centrais trazidas da literatura e do cinema, coincidente com a oposição escritor-cineasta presente na epígrafe, oposição que não vou desenvolver aqui. As duas referências aludidas estão dadas nas personagens Stephen Dedalus e Paulo Martins, respectivamente, das obras de James Joyce e de Glauber Rocha.

Com relação a Joyce, refiro-me ao diálogo estabelecido entre as personagens Stephen Dedalus, tida como seu alterego, e Cranly, na obra Retrato do artista quando Jovem. Ali, pode-se ler:

Para fora, pois; era tempo de ir. Uma voz falou suavemente ao coração solitário de Stephen, instigando-o a ir e lhe dizendo que a sua amizade ia seguindo para um fim. De fato; devia ir-se. Não podia competir com outro. Conhecia a sua parte.

- Provavelmente irei embora - disse. 
- Para onde? - perguntou Cranly.

- Para onde puder - disse Stephen.

- Ah! Sim - observou Cranly. - Ser-te-ia difícil viver aqui, agora.

Mas é isso que te obriga a ir?

- Tenho que ir - respondeu Stephen.

- Pois não precisas de exílio - continuou Cranly - Não te há de ser difícil manobrar a tua vida, caso não queiras te ir como um herege ou como um proscrito" (Joyce, 1987, p. 303).

Mais adiante, em seguimento ao diálogo entre Cranly e Dedalus, este diz:

- Olha aqui, Cranly - disse ele. - Tu me perguntaste o que eu faria e o que eu não faria. Vou te dizer o que farei e o que não farei. Não servirei aquilo em que não acredito mais, chame-se isso o meu lar, a minha pátria, ou a minha igreja: e vou tentar exprimir-me por algum modo de vida ou de arte tão livremente quanto possa, e de modo tão completo quanto possa, empregando para a minha defesa apenas as armas que eu me permito usar: silêncio, exílio e sutileza (Joyce, 1987, p. 305). ${ }^{2}$

Há algo nessas palavras que nos dá a dimensão da solidão vivida pelo poeta, pelo intelectual, pelo visionário. Nestes termos, ainda que por outros caminhos e sentidos, dados em um contexto político e dramático diverso, essa mesma configuração de uma espécie de autoconfinamento e de autoexílio pode ser percebida nas palavras da personagem Paulo Martins, no filme Terra em transe, de Glauber Rocha. Diz a personagem:

Quando a beleza é superada pela realidade,

Quando perdemos nossa pureza nestes jardins de males tropicais,

Quando no meio de tantos anêmicos respiramos

O mesmo bafo de vermes em tantos poros animais,

Ou quando fugimos das ruas e dentro de nossa casa

A miséria nos acompanha em suas coisas mais fatais

Como a comida, o livro, o disco, a roupa, o prato, a pele,

$\mathrm{O}$ fígado de raiva arrebentando, a garganta em pânico

E um esquecimento de nós inexplicável,

Sentimos finalmente que a morte aqui converge

Mesmo como forma de vida, agressiva (Rocha, 1985, p. 302).

\footnotetext{
2 No original:

"- Look here, Cranly, he said. You have asked me what I

would do and what I would not do. I will tell you what I will do and what I will not do. I will not serve that in which I no longer believe, whether it call itself my home, my fatherland, or my church: and I will try to express myself in some mode of life or art as freely as I can and as wholly as I can, using for my defence the only arms I allow myself to use silence, exile, and cunning" (2005, p. 212).
} 
Ou ainda:

Mar bravio que me envolve neste doce continente...

Posso morder a raiz das canas, a folha do fumo,

Posso beijar os deuses.

O milagre da minha pele morena-índia

A este esquecimento posso doar minha triste voz latina,

Mais triste que revolta, muito mais...

Vomito na calle o ácido dollar,

Avançando nas praças entre niños sucios

Com sus ojos de pajaros cegos,

Vejo que de sangue se desenha o Atlântico

Sob uma constante ameaça de metais a jato,

Guerras e guerras nos países exteriores.

Posso acrescentar que na Lua um astronauta se deu por achado.

Todas as piadas são possíveis na tragédia de cada dia.

Eu, por exemplo, me dou ao vão exercício da poesia

(Rocha, 1985, p. 302).

Se em Dedalus, o trinômio "silêncio, exílio e sutileza" (este último também como "astúcia", correspondente ao original "cunning”), são as suas armas de luta, são as maneiras as quais ele se propõe exprimir algum modo de vida e de arte, para além das fronteiras de Dublin; em Martins, que como o poeta Dedalus, vive à procura da beleza e da arte, o mundo é lido como um princípio de realidade brutal, consequência da desigualdade social, onde a miséria e a morte compõem nosso jardim de "males tropicas": onde e quando "a beleza é superada pela realidade". Martins vive uma ambivalência configurada pela tensão entre sua militância política e sua poesia. Ambas essas práticas o lançam no coração do mundo e no desespero. Talvez, aí, a personagem Paulo Martins possa sim ser identificada como uma espécie de alterego do cineasta, nos termos postos pelo próprio Glauber Rocha no trecho de carta citado em epígrafe acima.

Faço uso, neste momento, de um estudo de Miriam Volpe $(2003 ; 2005)$ sobre o escritor Mario Benedetti, que esboçou um conjunto variado de definições sobre a condição de exílio. Cabe aqui tomar por referência algumas dessas caracterizações por ele formuladas, tal como nos indica a autora. Com isso, miro a possibilidade de identificar no evento das personagens referidas neste ensaio, algum tipo de definição mais condizente com as suas trajetórias. ${ }^{3}$

3 Outras indicações sobre exílio e diáspora podem ser elencadas neste estudo, mas mais como referências bibliográficas sobre a temática, dados os limites deste trabalho e a natureza do debate que viso aqui, de tratar essas questões a partir de como as personagens as emanam, nos filmes em foco. A título de sugestão, lembro os já largamente referenciados $A$ identidade cultural na pós-modernidade e Da diáspora: identidades e mediações culturais, de Stuart 
Assim, os sentidos de geografias do exílio em Benedetti, como elencados por Volpe $(2003,2005)$, dizem respeito tanto às formas do espaço e do deslocamento quanto às das estruturas da consciência e dos processos mentais dos sujeitos. Ao situar a vida e a obra do escritor, a autora procura inscrevê-lo numa tradição de escritores, críticos e intelectuais das Américas "empenhados em quebrar a hegemonia e re-localizar a escritura" com vistas a uma negociação dos "espaços de enunciação" (Volpe, 2003, p. 46). Para ela, esses intelectuais

buscam propor uma auto-interpretação de sua história, arte e cultura, sem se considerar obrigados a aceitar o diagnóstico, não raras vezes, onipotente, que, sobre tais aspectos, elabora o mundo desenvolvido, mesmo que este seja expresso através de altos expoentes de sua intelligentsia (Volpe, 2003, p. 46).

Nestes termos, mostra-nos como Benedetti reconhece na crítica elaborada por escritores brasileiros, argentinos, chilenos e de outros países da região

[...] o esforço para propor uma dimensão e um ponto de vista latinoamericanos, tanto na crítica literária como na história das ideias, sem por isso desconsiderar o aporte da Europa e dos Estados Unidos, com o qual considera que podem concordar, ou discordar, de igual para igual (Volpe, 2003, p. 47).

Neste ponto, a autora vincula a biografia intelectual crítica do escritor a termos chaves como "o exílio, o intelectual latino-americano e a nação, o lugar de sua enunciação" (Volpe, 2003, p. 47), não apenas em termos teóricos e críticos, mas, inclusive, do ponto de vista da arte ficcional. E nos explica o uso do termo "geografias", aplicado em sua pesquisa, sobretudo, com ênfase a duas dimensões circunscritas a situações de exílio, qual seja, a espacial e a temporal. Assim, nos diz:

Hall (1997 e 2003, respectivamente) e O local da cultura, de Homi K. Bhabha (1998), para um debate cultural mais amplo. Há, igualmente, importantes estudos sobre questões do exílio e diáspora na experiência recente do Brasil e da América Latina, bem como, de um cinema com sotaque. Ver, por sua vez, para o cinema: Crítica da imagem eurocêntrica (Shorat e Stam, 2006); Rethinking third cinema (Guneratne e Dissanayake, 2003); An accented cinema: exilic and diasporic filmmaking (Naficy, 2001); Filmes da África e da diáspora: objetos de discursos (Bamba e Meleiro 2012) e Cinema, globalização e interculturalidade (França e Lopes 2010). Com relação à experiência do exílio no Brasil pós Golpe de 1964 e, sobretudo, após a edição do AI-5, em dezembro de 1968, ver: Memórias do exílio, Brasil, 1964-19?? Parte 1: De muitos caminhos (Cavalcanti e Ramos, 1978) e Exilio: entre raízes e radares (Rollemberg, 1999). Esses estudos, embora não detidamente trabalhados no corpo deste ensaio, compõem-se como fontes de motivação central para a sua escrita. Fica aqui como sugestões ao leitor. 
Ao refletir sobre situações de exílio, e suas variantes - o insílio e o desexílio - sugere-se uma ênfase na dimensão espacial, no sentido de estar, atravessar, sair, voltar a lugares, cidades, países, fronteiras, pontes, assim como também, de forma metafórica, de atitudes, estados de espírito, visões de mundo, ideologias. No entanto, é incluída, também, uma dimensão temporal, numa proposta de articulação dos tempos de vida de Mario Benedetti com os tempos da cultura em que sua trajetória se inscreve, dado que o escritor se autoproclama tradutor e testemunha desses tempos (Volpe, 2003, p. 47).

Embora reconheça o caráter problemático dos conceitos de exílio, de intelectual e de latino-americano, Volpe identifica em Benedetti que o "sentido formal e legal" do exílio, provocado pelas ditaduras teve efeito não apenas nos indivíduos, mas sobre as construções de identidades nacionais e sobre a cultura, o que afetou vários intelectuais.

Outro sentido do exílio diz respeito a pontos positivos aí ocorridos, ainda que não intencionais; processos paralelos de compaixão e crueldade envolvidos no tipo de hospitalidade reservada aos exilados, mas, para além da questão da hospitalidade, o reconhecimento das contribuições intelectuais que estes podem trazer para os países que os abrigam (Volpe, 2003, p. 48).

Por outro lado, o exílio dispõe tanto da acepção do afastamento do território de origem quanto dos processos de estrutura interna dos sujeitos, sua "condição mental" ou "estado de ânimo". Há, pois, várias conotações dadas ao exílio em Benedetti. Desde o vazio deixado pelo êxodo ao exílio interior (do sujeito que se aliena da realidade); há, também, o exílio residencial ou insílio (do sujeito forçado a uma atitude passiva pelas ditaduras); há o desexílio (do sujeito cuja nostalgia não se processa unicamente pelo desejo de volta, mas, igualmente, pelo que vai deixar ao voltar, numa experiência equivalente a uma contranostalgia, do sujeito dividido entre dois lugares: "estrangeiro em casa" e "em casa de estrangeiros") (Volpe, 2003, p. 48-49).

Exílio e diáspora se apresentam como conceitos distintos no importante estudo de Naficy $(2001 ; 2010)$. Como acentua o autor, o recorte de seu trabalho se volta para diretores cinematográficos que, postos numa ou noutra situação, atuam no interstício das "formações sociais e das práticas cinematográficas", no que ele configura como sujeitos "locais, mas universais" (Naficy, 2001, p. 10; Naficy, 2010, p. 138). Originários em sua maioria do hemisfério sul, de países classificados como de Terceiro Mundo ou de pós-coloniais, esses diretores vivem um processo de tensão e dissenso tanto com os seus países de origem quanto com as metrópoles para onde migram já desde os anos 1960. 
Em geral, atuam de forma independente, à margem dos modelos dominantes característicos das grandes indústrias cinematográficas e do sistema de estúdio, dentro do que Naficy chama de "modos de produção intersticiais e coletivos", numa posição crítica aos modelos hegemônicos (Naficy, 2001, p. 10; Naficy, 2010, p. 138).

Para ele, a constituição do estilo com sotaque desses diretores se deve, segundo sua pressuposição, a variações e similaridades relacionadas a um conjunto de questões: pelo fato de estarem mais propensos às tensões que a marginalidade e a diferença lhes impõem e os impedem de se tornarem hegemônicos como grupo ou mesmo um movimento; o fato de seu estilo com sotaque ser codificado pelas tensões e diferenças as quais compartilham, impedem igualmente que seus filmes sejam facilmente resolvidos por "narrativas conhecidas e esquemas genéricos". E afirma:

As variações entre os filmes são geradas por muitos fatores, enquanto suas similaridades se originam principalmente do que os diretores têm em comum a subjetividade liminar e a posição intersticial na sociedade e na indústria cinematográfica (Naficy, 2001, p. 10; Naficy, 2010, p. 138).

$\mathrm{O}$ autor identifica dois agrupamentos gerais aos quais os diretores com sotaque se encontram vinculados. O grupo da primeira fase, dos anos 1950 a 1970, teve sua motivação no processo de descolonização do Terceiro Mundo, de ocidentalização e de uma espécie de descolonização interna ao próprio Ocidente ("envolvendo os diversos movimentos pelos direitos civis, de contracultura e antiguerra"). Já o grupo da segunda fase, nas décadas de 1980 e 1990, foi motivado tanto pela "decadência do nacionalismo, do socialismo e do comunismo", quanto pelo advento das economias globais e a suposta fragmentação dos estados-nações; mas, também, pelo surgimento de novos processos de imigração, bem como a consolidação de novas tecnologias e as novas mídias (Naficy, 2001, p. 10-11; Naficy, 2010, p. 138-139): “os diretores com sotaque são o resultado desse deslocamento binário pós-colonial e dessa difusão pós-moderna ou modernidade tardia" (Naficy, 2001, p. 11; Naficy, 2010, p. 139).

Naficy diferencia, em seu mapeamento do cinema com sotaque, três tipos de filmes que o caracterizam, ainda que nos alerte para o fato de não se tratar de distinções fixas, chegando mesmo tais filmes a apresentarem, em sua maioria, as três características em diferentes níveis. Os tipos classificados são o "étnico, do exílio e da diáspora": "muitos diretores se mudam não apenas de um país para outro, mas também de um tipo de filme para outro, de acordo 
com a trajetória de suas viagens identitárias e de suas comunidades de origem" (Naficy, 2001, p. 11; Naficy, 2010, p. 139).

Por fim, para uma caracterização da condição de exílio e de diáspora relativamente ao cinema com sotaque, o autor nos indica como o primeiro pode ser interno ou externo, a depender do lugar para onde alguém é destinado. Por outro lado, como afirma Naficy, os constrangimentos vividos no contexto do autoritarismo pelos cineastas exilados internamente, com as restrições, as privações e a censura que lhe é imposta, os têm desafiado a desenvolverem um "estilo autoral". Nessa direção, o autor argumenta o fato de cineastas que poderiam escapar do exílio interno, mas que recusam tal procedimento com fins a uma luta justa em casa (Naficy, 2001, p. 11; Naficy, 2010, p. 140). Interessante perceber como essa assertiva nos remete, mais uma vez, para a epígrafe posta no início desta seção.

Essa luta com frequência define seu estilo fílmico, mas igualmente a estatura de sua identidade como figura opositiva. Ao trabalharem sob um regime interno de exílio, cineastas escolhem seus locais de luta e a sua potencial transformação na ordem social. Quando falam na condição de exilado interno, geram um determinado impacto. A prova de que são ouvidos estaria nas consequências desses atos com os constrangimentos vividos. Por outro lado, se eles falam na condição de exilado externo, com liberdade política, não são suficientemente ouvidos na "cacofonia" de vozes que competem para uma atenção no mercado (Naficy, 2001, p. 11; Naficy, 2010, p. 140). Atualmente, com os processos advindos com a globalização, diz o autor, os exílios sejam de ordem interna ou externa de um país não são demarcados de forma excludente. $\mathrm{Na}$ realidade, há muito tráfico e troca entre eles (Naficy, 2001, p. 11; Naficy, 2010, p. 140).

Digno de nota, contudo, quando se refere à ideia da cacofonia das vozes, à qual está submetida a condição de exilado externo dos diretores com sotaque, é a substituição que Naficy propõe à pergunta de Spivak (2010), sobre se os subalternos podem falar. Para ele, a pergunta que deverá substituir aquela é sobre se podem os subalternos ser ouvidos. A questão é tanto mais pertinente à medida que, em seu estudo, o autor vai dedicar atenção especial, ao falar de exílio, à condição de exilados externos dos diretores com sotaque (Naficy, 2001, p. 11; Naficy, 2010, p. 140-141).

Ao distinguir exílio e diáspora, o autor afirma que um e outro têm seu início marcado por traumas, rupturas, coerções, e envolve a dispersão de populações de seus lugares de origem. Se o exílio pode se identificado como individual ou coletivo, as teorias da diáspora tendem a identificá-la como de natureza necessariamente coletiva, visto que nela há sempre a construção 
de uma memória coletiva, de um lugar de origem idealizado. Há também a manutenção de uma consciência de distinção étnica. Cineastas da diáspora não são tão centrados como os cineastas exilados, numa espécie de relacionamento catequizado com a pátria, e não reivindicam ser o seu representante. Seus trabalhos são menos expressos em narrativas de retrospecção, perda e ausência ou em modos estritamente partidário de condições políticas. Seus filmes têm um maior sotaque que os dos cineastas exilados, dada a pluralidade e identidade performativa de seus processos. Como indica Naficy:

Os cineastas diaspóricos tendem a se concentrar menos que os do exílio nas relações emotivas com um único país de origem ou na asserção de que eles representam seu país e seu povo. [...] seus trabalhos não se detêm em retrospecção, perda e falta ou em termos estritamente político-partidários. Seus filmes são marcados mais que os filmes de exílio pela pluralidade e pela representação da identidade. [...] enquanto o binarismo e subtração marcam os filmes de exílio, a adição e a multiplicidade caracterizam o cinema diaspórico (Naficy, 2001, p. 14; Naficy, 2010, p. 146).

No que pese a relevância dessa discussão para um melhor entendimento das implicações contidas nas ideias de exílio e diáspora, particularmente no tocante ao fato de ser este um estudo sobre essa realidade no cinema periférico, deixo claro que não estou com isso orientando o trabalho para uma análise dos cineastas cujos filmes, mormente os seus personagens centrais, são matéria de discussão neste ensaio. Nesse sentido, não desejo que o foco de atenção que esse debate traz recaia diretamente sobre as figuras de Glauber Rocha, como modelo de exilado, e Walter Salles e Daniela Thomas, como expressão diaspórica. Ainda que se tenha clareza quanto ao cosmopolitismo e desterritorialização desses cineastas e quanto à questão de que, em Glauber, muitas das suas idas e vindas, no contexto das adversidades políticas, estavam relacionadas a uma forma de exílio, mais especificamente, quando de sua partida para a Europa no ano de 1971. Diferentemente, o processo de desterritorialização vivenciado por Salles, dos 3 aos 13 anos, esteve relacionado à sua origem familiar, pelo fato de o pai ter sido embaixador. Curiosamente, como em declarações já feitas por ele, a questão da identidade se manifesta como aspecto central de seu trabalho, tal como se pode reconhecer no conjunto de sua obra.

Feita essa ressalva, portanto, afirmo que minha intenção não é outra senão a de termos mais elementos para uma reflexão que nos permita vislumbrar um sentido de exílio e diáspora relativamente aos modos como esses termos podem servir de importantes chaves de entendimento dos traços gerais que marcam 
o texto/contexto que caracteriza os perfis das personagens Paulo Martins e Paco, em face dos impasses em que se veem frente a episódios decisivos em suas histórias de ficção; e de como essas histórias estão em diálogo e referidas a momentos históricos específicos e recentes ocorridos em nossa sociedade. A saber, o momento de instauração do golpe de estado pelos militares em 1964 e o momento de redemocratização e retorno ao estado de direito, na segunda metade da década de 1980 .

\section{Paulo Martins ou "Política e poesia são demais para uma só pessoa"}

Uma consciência melancólica do mundo parece ser uma das características mais marcantes da personagem Paulo Martins, a ponto de levar seu comportamento a se manifestar por uma espécie de revolta resignada (ou, ao menos, por uma certa tensão entre estados de revolta e de resignação), mas, também, a uma constatação da tragédia como "realidade" que supera a "beleza", daí o sentido de se dar "ao vão exercício da poesia", conforme citação no início da seção anterior deste ensaio. Daí, também, o sentido de um autoexílio manifesto na forma recorrente com que o poeta se põe a condição de esquecimento, como nas passagens:

'... quando fugimos das ruas e dentro de nossa casa/A miséria nos acompanha em suas coisas mais fatais/Como a comida, o livro, o disco, a roupa, o prato, a pele,/O fígado de raiva arrebentando, a garganta em pânico/E um esquecimento de nós inexplicável/ Sentimos finalmente que a morte aqui converge/Mesmo como forma de vida, agressiva...' e 'A este esquecimento posso doar minha triste voz latina,/Mais triste que revolta, muito mais... (Rocha, 1985, p. 302).

Pode-se, contudo, identificar outros aspectos envolvidos na caracterização dessa personagem, de modo a melhor refletirmos a sua complexidade, em termos de sua constituição pelo autor. Nesse sentido, faço aqui referência ao estudo que Bentes (1999) elabora, com foco em questões de estética e política no cinema, sobretudo, com relação ao cinema de Glauber Rocha, num pequeno dossiê de ensaios que têm como fonte, dentre outros documentos, as cartas do cineasta. Nesses ensaios, ela ressalta como um ponto chave a radicalidade do cineasta na recusa em assumir uma posição de conciliação ou de paternalismo quanto à "representação das relações de poder e de saber entre o intelectual e o povo" (Bentes, 1999, p. 338). Contra essa visão, que legitima o intelectual como representante do povo e põe este numa perspectiva de vitimização, Rocha propõe uma "pedagogia da dor e da violência", que 
considera essencial para a "constituição de um povo, de fabulação" (Bentes, 1999, p. 344). Diz a autora:

Nesses filmes, o povo é chicoteado, espancado, amordaçado, fuzilado. Ao invés de condenar 'moralmente' a violência e exploração, representa essa violência com tal radicalidade e força que ela passa a ser um intolerável para o espectador. Glauber também aponta novos agentes e intermediários nesse processo (o cangaceiro, o beato, o mercenário) que destituem o intelectual do seu lugar privilegiado de agente de transformação (Bentes, 1999, p. 338).

Quatro são as tipologias de povo representadas nos filmes de Glauber, conforme as analisa Bentes: o tipo mitológico, ligado a "estruturas míticas"; o tipo representado como natureza, da terra e confundido com a paisagem; o tipo constituído como alteridade, o "Outro", e o tipo que identifica o povo tanto como a "vítima dos processos de dominação" quanto como o "agente da revolução" (Bentes, 1999, p. 342-343). Com relação a este último tipo, Bentes dedica maior atenção em seu estudo, visto que, como acentua, é nele que "a torção glauberiana, seu pensamento político, faz passar da passividade à atividade" (Bentes, 1999, p. 343).

Neste ponto, a ênfase recai sobre filmes como Terra em transe (entre outros), onde Glauber configura personagens, a exemplo de Paulo Martins, como que dotados do que ela conceitua como "pulsões anarco-ditatoriais da elite” (Bentes, 1999, p. 344). Diz Bentes:

Com 'Terra em transe', Glauber coloca esse povo (subserviente, vitimizado, fraco) em questão com a mesma radicalidade e paroxismo com que criticou o intelectual de esquerda, Paulo Martins, um Hamlet tropical, entre banhos de sangue e exaltação poética, em estado de possessão. Esse tipo de representação crua de um povo despotencializado e assujeitado combinado com uma pedagogia da violência produziu certa animosidade na esquerda (Bentes, 1999, p. 344).

E ainda:

podemos dizer que seu cinema [de Glauber] é atraído pelo que chama de 'fascismo esplendoroso', na tentativa de montar cinematograficamente uma mitologia de esquerda que pudesse suplantar a mitologia 'colonizadora'. Nesse esforço e proposta descomunal vai se apropriando e fazendo torções de tudo que puder servir de estofo à sua construção mítica (Bentes, 1999, p. 344). 
A ambivalência vivida pela personagem Paulo Martins, de resto, embora não seja um reflexo imediato das contradições recorrentemente identificadas na condição intelectual vis-à-vis o poder na modernidade, encontra-se mediado por elas. Quando nos indagamos sobre a condição do intelectual no processo histórico de constituição do estado-nação moderno, sobretudo em contextos periféricos, logo nos deparamos com um quadro de situações que vão do encantamento à abnegação; da missão e engajamento como vocação intelectual à ideia de pensamento independente, livre, autônomo; da revolta à resignação e, no mais das vezes, ao distanciamento e ao autoexílio. De resto, o tema da condição intelectual é já amplamente discutido na literatura sociológica e de teoria social, particularmente, no tocante à construção de sentidos da identidade nacional, da desigualdade social dos povos e, mais recentemente, dos processos de globalização. Não vou, no entanto, no limite de espaço deste ensaio, passar em revista essa literatura. Algumas referências, em todo caso, estão contidas na bibliografia.

Ainda com relação a Paulo Martins, a dificuldade de se traçar um perfil da personagem se dá pelo fato de se se situar num labirinto de contradições no que diz respeito à construção de sua identidade como poeta e como político e as ambiguidades de caráter ético e moral, situadas em sua postura política. Seu espírito de missão e suas íntimas relações com o poder, tanto populista de esquerda quanto fascista de direita. Seu nacionalismo e sua posição desterritorializada (Bentes, 1999, p. 340). Sua crença num projeto coletivo e sua arrogância e sentimento de superioridade em relação ao povo: numa cena em que Jerônimo, um líder operário, fala de uma grande crise que o país enfrenta e que "o melhor é esperar a ordem do Presidente..." (Rocha, 1985, p. 313), Paulo Martins o silencia bruscamente, pondo a mão na boca do líder para, em seguida, dizer: "está vendo o que é o povo? Um imbecil, um analfabeto, um despolitizado! Já pensaram Jerônimo no Poder?” (Rocha, 1985, p. 313).

Numa cena anterior, de conflito com camponeses sobre a posse da terra, que estava sendo reivindicada por fazendeiros que apoiaram o governador Vieira, Paulo bate num camponês que o enfrenta. Em seguida, relata a Sara (militante e intelectual que o leva da Capital para a província de Alecrim):

E eu fui lá, bati num pobre camponês porque ele me ameaçou... Podia ter metido a enxada na minha cabeça, mas ele era tão covarde e tão servil! E eu queria provar que ele era covarde e servil... A fraqueza... gente fraca... sempre... gente fraca e com medo... (Rocha, 1985, p. 297). 
Numa outra cena em que se encontra abraçado com Sara no meio do povo, Paulo diz um poema, a voz em off:

Qual o sentido da coerência?/Dizem que é prudente observar a História sem sofrer./Até que um dia, pela coincidência,/As massas tomem o poder.../Ando nas ruas e vejo o povo fraco, abatido,/Este povo não pode acreditar em nenhum partido./Este povo cuja tristeza apodreceu o sangue/Precisa da morte mais do que se pode supor./O sangue em que seu irmão estimula a dor,/O sentimento do nada que faz nascer o amor,/A morte enquanto fé e não como temor (Rocha, 1985, p. 312).

Uma questão que se pode colocar, no tocante ao engajamento românticopolítico de Paulo Martins, é se este pode ser um aspecto decisivo na explicação de seu enfrentamento suicida diante do impasse em que se viu colocado, ainda mais quando o cenário desenhado pela situação é a de uma amarga derrota do projeto político que ajudou a construir. Sentindo-se traído e isolado, por ser o único do grupo a defender uma resistência armada contra o movimento que ameaçava depor Vieira, caso ele não renunciasse, Paulo não vê outra saída a não ser a de se lançar a um ato tão dramático. Quando perguntado por Sara sobre o que prova a sua morte, Paulo responde que ela é "o triunfo da beleza e da justiça”. A certa altura, num momento de quase delírio, Paulo grita que é preciso resistir e que ele precisa cantar. Numa alusão, talvez, à música Marcha da Quarta-feira de Cinzas, de Vinicius de Moraes e Carlos Lyra. Mesmo o filme inicia com uma epígrafe do poeta piauiense Mário Faustino (2010):

Não conseguiu firmar o nobre pacto

Entre o cosmo sangrento e a alma pura...

Gladiador defunto, mas intacto

(Tanta violência, mas tanta ternura) (Faustino, 2010, p. 135).

Outro ponto de interrogação é se os modos de incompreensão política que Paulo experimentará, seja na seara dos políticos, seja frente ao comportamento das massas seria a condição fundante para a ambivalência com que ele posiciona a sua forma de engajamento, ora manifesta numa militância direta, ora distanciada. No ímpeto de dar seguimento às reformas políticas e sociais assumidas em campanha junto ao povo, Paulo demonstra impaciência com relação aos limites de poder enfrentados pelo governador Vieira, que cede ante a pressão que sofre até dos aliados poderosos, a quem deve favores políticos e cujos interesses entram em choque direto para com o projeto de mudanças junto à maioria. Seria, ainda, o autoexílio de Paulo Martins movido pela sua 
condição de poeta e intelectual, utópico e visionário, mas, também, cético em relação às massas e ao poder? Numa discussão acirrada com Sara, esta lhe diz: "Política e poesia são demais para uma só pessoa". Este é um momento em que Paulo, ao perceber o não cumprimento do projeto político que ajudara a construir, abandona o governo de Vieira. Após sugerir a ruptura com a área federal, dado os conflitos e assassinatos pela posse de terra, e receber de Vieira a resposta de que "Política se faz com habilidade", Paulo se demite, numa cena em que diz:

Então eu me demito... Um dia, quando for impossível impedir que os famintos nos devorem, então veremos que a falta de coragem, que a falta de decisão... E o que é você, Viera? Diga.. Um líder? (Rocha, 1985, p. 298-299).

Noutra cena, com Sara, num momento em que se beijam longamente, Paulo confirma sua saída do governo. A cena se desenrola num diálogo tenso:

Paulo

"Pois eu recuso a certeza, a lógica, o equilíbrio... Eu prefiro a loucura de Porfírio Diaz... Sou filho desta loucura..."

Sara

"Assim é tão fácill!"

Paulo

"Fácil? Rompendo com tudo e com todos? Sacrificando as mais fundas ambições?"

Sara

"O que sabe você das ambições? Eu queria me casar, ter filhos como qualquer mulher! Eu fui lançada no coração do meu tempo, eu levantei nas praças meu primeiro cartaz, eles vieram, fizeram fogo, amigos morreram e me prenderam e me deixaram muitos dias numa cela imunda com ratos mortos, e me deram choques elétricos, me seviciaram e me libertaram com as marcas e mesmo assim eu levei meu segundo, terceiro e sempre cartazes e panfletos e nunca os levei por orgulho. Era uma coisa maior, em nome da lógica dos meus sentimentos!... E se foram a casa, os filhos, o amor... as ambições normais de uma mulher normal... De que outras ambições individuais posso falar que não seja a de felicidade entre pessoas solidárias e felizes?"

Paulo

"A fome do absoluto..."

Sara

"A fome?" 


\section{Paulo}

"Eu tenho esta fome. Vem comigo, não fique com os fanáticos à espera de coisas que não acontecem antes que nos acabemos. Vem comigo, Sara! A vida está acima das horas que vivemos, a vida é uma aventura!"

\section{Sara}

"Você não entende... Um homem não pode se dividir assim... A política e a poesia são demais para um só homem... Eu gostaria muito que você ficasse conosco... Volte a escrever..." (Rocha, 1985, p. 300).

No contexto do filme, aliás, o projeto político de Vieira está marcado por entraves profundos no tocante às reformas sociais, particularmente, por seu caráter populista - importante tendência localizada tanto nas alegorias fílmicas desse lugar imaginário, o El Dourado, quanto, dialogicamente, nos regimes políticos da América Latina desde o pós-guerra; sendo o populismo uma das principais causas no tocante à fragilidade política e institucional do processo democrático na região, cujo cenário é o da manutenção de extremas desigualdades e de mitigadas reformas sociais, ancoradas numa espécie de paternalismo estatal, personificado na figura do governante (tipo carismático que, por força da ação patrimonialista, toma para si um modelo de reformas sociais de cunho salvacionista).

Como assinala Ismail Xavier, o que Terra em transe traz

é uma demonstração ao vivo da força desse universo das imagens e de como, para pensar a política, é preciso pensar o campo simbólico e não achar que você vai limpar a realidade desse universo todo e vai produzir uma explicação cristalina de qual é o processo que está sendo vivido (Xavier in Rocha e Pizzini, 2006).

Para ele, o que Terra em transe encena como resposta ao golpe de estado de 1964, pode ser manifesto em dois movimentos aí ensejados: o que foi o ideário da direita golpista; e uma visão crítica da esquerda, a partir de uma dissecação do "teatro do populismo". A questão que Xavier nos coloca, pois, é a da realidade fílmica, que traduz isso em drama, ao inventar personagens, ao criar determinadas máscaras capazes de condensar tudo isso numa postura política (Xavier in Rocha e Pizzini, 2006).

\section{Paco ou a diáspora em reverso}

De uma certa forma, se há um tema que perpassa quase todos os filmes que fiz até hoje, é o do exilio declinado nas suas mais 
diversas formas. O do exílio afetivo em que tanto Josué quanto Dora se encontram em Central do Brasil, o exílio dentro da própria família que caracteriza os filhos de Abril Despedaçado, o exílio voluntário pelo qual o jovem Ernesto Guevara opta em Diários de Motocicleta (para abraçar outros exilados), o exílio psicológico da mãe de Água Negra, as diferentes formas de exílio (econômico ou afetivo) que definem a família de Linha de Passe. Mas se há um filme em que todas as formas possiveis de exílio se encontram, é Terra Estrangeira, correalizado por Daniela [Thomas]. Exílio politico e econômico (os anos Collor), exílio amoroso, e até exílio no sentido mais literal da palavra - o da pátria.

(Walter Salles in Strecker, 2010)

A personagem Paco, de Terra estrangeira, já previamente identificada em seção anterior, traça o perfil de um jovem estudante, aspirante a ator de teatro, residente em São Paulo, aparentemente despolitizado e dependente, que se encontra perdido quando do desaparecimento de sua mãe que, como vimos, morre numa situação de grande adversidade, ao ser frustrada em seu projeto de retornar a sua cidade natal, San Sebastian, na Espanha, a fim de revê-la e de apresentá-la a seu filho. Embora Manuela já surja em cena com a aparência de quem está muito cansada, é só após o anúncio do confisco da poupança promovido pelo governo Collor que se dá o colapso fatal ao qual ela não resiste.

Sem ter a quem recorrer e à deriva, Paco se lança numa perigosa aventura, por se dar num contexto desfavorável, de ir à procura de suas origens mais ancestrais, mas, por isso mesmo, em abandono às suas origens mais imediatas, numa dada situação que eu chamarei aqui, de modo inapropriado, de uma espécie de diáspora em reverso: em que o mito de origem, a comunidade imaginada, não se encontra no lugar de onde se parte, mas para onde se vai.

A situação é bem emblemática, visto que Paco não demonstra, no início do filme, grande interesse em conhecer o lugar de nascimento da mãe. Ao contrário, chega mesmo a propor o adiamento da viagem, uma vez que isso implicava em despesas maiores que os recursos que dispunham. Após a morte de Manuela, Paco percebe que não pode permanecer no lugar onde reside, como se se sentisse um estrangeiro em casa. Por estar muito abalado com a situação de perda que teve que enfrentar, vê seu sonho de ser ator malograr, por não ter conseguido realizar a cena-teste que o permitiria entrar para o teatro.

Desse momento em diante, San Sebastian passa a ser o lugar de destino, mas, em certo sentido, como um lugar de origem. Há uma cena, no final do filme, no momento de fuga, em que Alex lhe faz a pergunta sobre o que ele 
vai fazer na cidade espanhola, e ele diz não saber, diz que vai olhar o lugar por alguém. Antes, num momento de desentendimento, Alex havia dito para ele voltar para o Brasil, e ele responde que não quer voltar.

Se o desespero de Paulo Martins, de Terra em transe, pode ser revelador de um profundo desencantamento para com o desando de um projeto político coletivo que ajudara a construir, significando o seu enfrentamento às forças da opressão uma atitude dramática de não aceitação da derrota iminente de um tão decantado anseio por mudanças; no filme Terra estrangeira, a situação de Paco não é unicamente a representação simbólica de uma tragédia pessoal, e sim, além disso, a expressão alegórica de uma tragédia que marca toda uma geração, de "personagens perdidos", que "vivem uma história de desesperança e de urgência" (Strecker, 2010, p. 104).

O ponto de chegada dessas personagens perdidas é Portugal. O lugar identificado como a porta de entrada da Europa, ainda que, no período vivido no filme, o país ainda mantivesse postos de fronteira com a Espanha. Para lá migram, principalmente, sujeitos oriundos de ex-colônias portuguesas - como que por redenção, num reencontro com o retrato do colonizador/pai/fundador? Daí talvez a forte presença localizada no filme, além de brasileiros, de caboverdianos, guineenses, angolanos, moçambicanos - alguns em situação irregular. Veja-se a visão de Salles a respeito dessa relação:

Portugal é ao mesmo tempo o pai e país que nos foi próximo e que, naquele momento, começava a nos rejeitar. Como eles mesmos são ou foram rejeitados pelo resto da Europa começaram a rejeitar os seus filhos, não somente brasileiros, mas toda aquela colônia que é conhecida em Lisboa como sendo a colônia 'pretoguesa'. A gente percebeu que o filme tinha que mudar. Em vez de ser um filme só de brasileiros que estavam no exílio, devia falar de um exílio mais amplo, uma espécie de contracampo da colonização portuguesa. Hoje, você vê essas populações que a gente encontrou à margem de Lisboa também à margem de Paris, de Londres. Isso não estava completamente claro em 1994 (Salles in Strecker, 2010, p. 106).

Portugal como lugar para onde convergem sonhos que se despedaçam em desesperanças, onde ninguém se encontra e todos se perdem. Há uma cena de diálogo entre Paco e Pedro, dono da livraria e amigo de Alex e Miguel, de quem Paco estava à procura para entregar um violino. $\mathrm{O}$ encontro dos dois se dá após a morte de Miguel, de quem Paco viu o corpo ser retirado do apartamento pelos policiais. Este é o momento em que Paco vê cair do bolso de Miguel um cartão com o endereço da livraria no qual consta o nome de Alex, o que o leva a procurar Pedro, para falar da encomenda que trouxe. 
Pedro despista qualquer informação sobre Miguel e, com a insistência de Paco, finaliza o diálogo com a seguinte fala:

Pedro

Esta é a primeira vez que você vem a Portugal, não é? Posso the dizer uma coisa? Isto aqui não é sítio pra encontrar ninguém, isto é uma terra de gente que partiu pro mar... É o lugar ideal pra perder alguém... Ou pra se perder a si próprio... Vai-te (Salles e Thomas, 1996).

A referência ao naufrágio é a principal metáfora com que Strecker inicia o seu comentário tanto aos "expatriados" de Terra estrangeira quanto à relação Portugal e Brasil. Leia-se, num primeiro momento, suas palavras em consideração ao filme:

O ponto de partida de Terra estrangeira é a foto de um navio encalhado em uma praia. É a imagem poética e bela, uma metáfora para o naufrágio de grandes promessas irrealizadas, para personagens à deriva mergulhados na solidão e na desesperança. $\mathrm{O}$ título parte de um grafite que o diretor tinha avistado: 'O amor é uma terra estrangeira' (Strecker, 2010, p. 104).

Noutra passagem, a propósito do "jogo de espelhos" da relação Brasil e Portugal, igualmente a metáfora do naufrágio se faz presente:

Portugal está no ponto mais ocidental da Europa, onde simbolicamente o velho continente acaba. Depois dele, só o desconhecido, o Novo Mundo. Para o Brasil e Portugal, trata-se de um jogo de espelhos. Para o imaginário lusitano, o Brasil também era o naufrágio da profecia do Quinto Império, uma utopia que colocaria os portugueses à frente de uma grande e nova civilização (Strecker, 2010, p. 105).

Para corroborar com a imagem do navio encalhado, posta na primeira citação, trago duas cenas do filme, bem reveladoras da solidão, do desencanto e do medo vivido por algumas das personagens no filme - particularmente, com referência ao modo como a personagem Alex se manifesta, em suas hesitações diante da vida. É o que se pode tirar, primeiramente, de uma cena em que ela e o companheiro Miguel conversam, num despertar do dia na cidade de Lisboa:

Alex

"Eu gosto dessa cidade essa hora... Cidade branca... Bonita, né? Só que às vezes me dá um medo..." 
Miguel

"Medo? Medo de quê?"

Alex

"Ah! Medo de você dançar e eu ficar sozinha aqui, num lugar que eu nem escolhi pra viver..."

Miguel

"Então, a gente pode ir pra onde você quiser Alex..."

Alex

"Você não tá entendendo... Não depende do lugar... Quanto mais o tempo passa mais eu me sinto estrangeira... Cada vez mais eu tenho consciência do meu sotaque... De que minha voz é uma ofensa pro ouvido deles... Sei não, eu acho que estou ficando é velha, viu?..."

Miguel

"Você tá ficando é doida, Alex... Pô, você só tem 28 anos..."

Alex

“É... 28? 30, 40, 50, 60... Caramba! Tá passando tão depressa... Depois eu morro de medo de ficar velha aqui fora, viu?... Mas, aí, também eu penso em voltar pro Brasil... Nossa, me dá um frio na espinha..." (Salles e Thomas, 1996).

Noutro momento, na cena de fuga para San Sebastian, de carro, quando procuram localizar a cidade num mapa, e após Paco dizer que vai lá para olhar o lugar por alguém, segue-se o seguinte diálogo entre ele e Alex:

\footnotetext{
Alex

"Nossa! Eu acho que não quero mais olhar pra coisa nenhuma na minha vida, viu?... Eu queria tanto voltar pra casa..."

Paco

"E onde é que é tua casa?"

Alex

"Boa pergunta... Sei que aqui que não é, né?... Sei lá, viu? Moema, Duque de Caxias, Moca... Eu acho que eu ficava feliz até se eu morasse debaixo do Minhocão, viu?"

Paco

"Eu morava de frente pro Minhocão..."

Alex

“Jura? Pô, desculpa eu não falei por mal...” (Salles e Thomas, 1996).
}

Melancolia e desamparo parecem ser o que move o sentimento de Alex, que, de resto, compõem um importante elemento de identificação de algumas das personagens no filme, cujas vidas encontram-se praticamente anestesiadas por um cotidiano de subsistência, sem se nutrir ao menos das velhas esperanças, dos antigos sonhos; ao contrário, neles reconhecendo não mais que ilusões 
perdidas. Ao expor a fala de Alex como representativa da situação vivida por outras várias personagens, o faço por entender que, em Terra estrangeira, uma personagem não é una, mas, múltipla. Paco é múltiplo, assim como Alex e Miguel; assim como os outros quase anônimos migrantes africanos.

Obras ficcionais se constroem num tempo-espaço relativo. Seu diálogo seja com imperativos supostamente atemporais seja com a contingência histórica, dada igualmente num tempo-espaço, tem sua configuração e seu processo enredados ao mesmo tempo como invenção e como reflexão, dadas em relação ao meio. Nesse sentido, a quê respondem Terra em transe e Terra estrangeira? São suas personagens, a um só tempo unas e múltiplas, marcadas por quais circunstâncias? Por quais estruturas de sentimento, no sentido evocado por Williams (1979)?

Se em Paulo Martins assiste-se ao decantar de um sonho de libertação que logo se transmuda em desilusão, que o leva a se recolher num ensimesmamento para dele sair na forma do herói, que deve sacrificar a vida em favor das causas nobres; em Paco não há causa aparente, apenas a urgência e o imediatismo da sobrevivência em terra devastada. O limiar entre vida e morte. O coletivismo atomizado. Não mais o Fausto da teatralização, mas o anonimato e a precariedade da vida ordinária.

Quando discute com os comparsas o destino de Paco, pelo sumiço do violino, Igor confirma que ele nada sabia sobre o que se escondia na caixa do instrumento, a ponto de compará-lo a uma virgem. Quando, no entanto, Paco percebe que a situação não é outra senão correr ou morrer lembra-se dos versos que se esqueceu de interpretar no teste para o teatro, e os recita no exato momento em que se prepara para a fuga:

Sinto meus poderes aumentarem... Sinto meus poderes aumentarem! Ardendo, bêbado de um novo vinho. Sinto a coragem, o ímpeto de ir ao mundo, de carregar a dor da Terra e o prazer da Terra. De lutar contra tempestades e enfrentar a ira do trovão.

Nuvens se ajuntam sobre mim. A lua esconde a sua luz, a lâmpada se apaga. Devo levantar... Devo levantar! Eu não era nada e aquilo me bastava. Agora não quero mais a parte, eu quero da vida o todo. Espíritos pairam próximos, me ouvem. Desçam! Desçam dessa atmosfera áurea. Levem-me daqui para uma vida nova e variada. Que o manto mágico seja meu e me carregue para terras estrangeiras.

Vou levantar... Que minha vida seja o custo!

(Goethe ${ }^{4}$ in Salles e Thomas, 1996).

\footnotetext{
${ }_{4}$ Na tradução de Jenny Klabin Segall, para a edição da Edusp/Itatiaia (1981):

"Quão outro, em mim, é deste signo o efeito!

Tu, Gênio térreo, me és vizinho;
} 
Ambos os filmes em que as personagens em estudo transitam (Terra em transe e Terra estrangeira) enredam-se em narrativas sobre a derrota política e os traumas que ela engendra em configurações históricas e na memória coletiva. Se o desencantamento em Paulo Martins ainda pode ser decantado sob a aura do que Ridenti (2005) chamou de "estrutura de sentimento da brasilidade (romântico-) revolucionária" (Ridenti, 2005, p. 83), referindo-se, grosso modo, à produção cultural e artística dos anos 1960; em Paco, e demais personagens de Terra estrangeira, a desesperança e a desidealização das coisas podem ser expressas na forma como Salles intitulou um de seus textos, que trata de outras questões: "Panaméricas não utópicas" (Salles in Strecker, 2010, p. 174) - numa clara alusão ao romance PanAmérica, de José Agrippino de Paula e aos versos de Sampa, canção de Caetano Veloso ("Pan-Américas de Áfricas utópicas..."), que, numa homenagem a cidade de São Paulo e como que num balanço de época, justamente a do início de sua carreira nos idos dos 1960, faz a referência ao romancista e cineasta José Agrippino de Paula, como também, aos poetas concretos, a Rita Lee e a outros artistas e manifestações culturais com as quais dialogou.

O termo cunhado por Salles, por certo, é revelador de um olhar desencantado, não ingênuo, de uma América Latina que teve à prova o fiasco que foi o seu projeto de modernização, claramente alinhado e dependente do modelo hegemônico de capitalismo ocidental; na mesma medida em que, por outro lado, viu a esquerda amargar uma situação de derrota de um projeto de libertação que se perspectivava na utopia de um pan-americanismo, sob o

Alçam-se as forças em meu peito,

Sinto a abrasear-me um novo vinho,

A opor-me ao mundo já me alento,

A sustentar da terra o júbilo, o tormento,

A arcar com o furacão e o vento,

E no naufrágio a ir-me, sem lamento.

Nubla-se o espaço sobre mim -

Oculta a lua o seu clarão -

A luz se esvai!

Sobe um vapor! - Coriscam raios rubros

À minha volta! - Um sopro frio

Desce da abóbada e me invade!

Espírito implorado,

Sinto que ao meu redor estás flutuando, enfim!

Revela a face!

$\mathrm{Ah}$ ! Como se lacera o coração em mim!

Em rasgos desmedidos,

Como se inflamam meus sentidos!

Sinto a alma inteira a ti oferecida!

Surge, pois! Surge, sim! Custe-me, embora, a vida!” (p. 43-44). 
signo do nacionalismo e, mais tarde, do lema de uma revolução tricontinental, nas palavras de ordem de Che, cujo imperativo era o da necessidade de se criar, nesta banda do mundo, muitos Vietnam.

\section{Referências}

ALTMANN, Elska. O Brasil imaginado na América Latina: a crítica de filmes de Glauber Rocha e Walter Salles. Rio de Janeiro: Contra Capa Livraria, 2010.

ASHCROFT, Bill; AHLUWALIA, Pal. Edward Said: la paradoja de la identidade. Barcelona: Edicions Bellaterra, 2000.

AVELLAR, José Carlos. A ponte clandestina: Birri, Glauber, Solanas, García Espinosa, Sanjinés, Alea - teorias de cinema na América Latina. São Paulo: Editora 34, 1995.

BHABHA, Homi K. O local da cultura. Belo Horizonte: UFMG, 1998.

BAMBA, Mahomed; MELEIRO, Alessandra (Orgs.). Filmes da África e da diáspora: objetos de discursos. Salvador: Edufba, 2012.

BENTES, Ivana. Transe, crença e povo: Glauber e a pedagogia da crise. In: Ângela Maria Dias. A missão e o grande show: políticas culturais no Brasil - anos 60 e depois. Rio de Janeiro: Tempo Brasileiro, 1999.

BERNARDET, Jean-Claude. Cineastas e imagens do povo. São Paulo: Brasiliense, 1985.

CAVAlCANTI, Pedro Celso Uchôa; RAMOS, Jovelino (Coords.). Memórias do Exílio, Brasil, 1964-19??. Parte I - De Muitos Caminhos. São Paulo: Editora e Livraria Livramento, 1978.

DOMINGUES, José Maurício. Do ocidente à modernidade: intelectuais e mundança social. Rio de Janeiro: Civilização Brasileira, 2003.

FAUSTINO, Mário. O homem e sua hora e outros poemas. São Paulo: Companhia das Letras, 2010.

FRANÇA, Andréa; LOPES, Denilson. Cinema, globalização e interculturalidade. Chapecó: Argos, 2010.

GOETHE, Johann Wolfgang von. Fausto. Belo Horizonte: Ed. Itatiaia, 1981.

GOETHE, Johann Wolfgang von. Fausto. Martin Claret: São Paulo, 2002.

GOMES, Paulo Emílio Salles. Cinema: trajetória no subdesenvolvimento. 2. ed. Rio de Janeiro: Paz e Terra, 1986.

GRAMSCI, Antonio. Os intelectuais e a organização da cultura. 4. ed. Rio de Janeiro: Civilização Brasileira, 1982.

GUNERATNE, Anthony R.; DISSANAYAKE, Wimal (Orgs.). Rethinking Third Cinema. New York: Routledge, 2003.

HALL.Stuart. Identidades culturais na pós-modernidade. Rio de Janeiro: DP\&A, 1997.

HALL.Stuart. Da diáspora: identidades e mediações culturais. Belo Horizonte: Editora UFMG, 2003. 
JACOBY, Russell. Os últimos intelectuais: a cultura americana na era da academia. São Paulo: Trajetória Cultural/Edusp, 1990.

JOYCE, James. Retrato do artista quando jovem. Rio de Janeiro: Ediouro, 1987. $<$ http://groups.google.com/group/digitalsource>

JOYCE, James. A portrait of the artist as a young man. Hazleton: The Pennsylvania State University, 2005. [The Electronic Classics Series, Jim Manis, Editor] <www.ebooksdirectory.com/details.php?ebook=3029>.

MEMMI, Albert. O retrato do colonizado precedido pelo retrato do colonizador. Rio de Janeiro: Paz e Terra, 1978.

MOREIRAS, Alberto. Epistemología ténue (sobre el latinoamericanismo). Revista de Crítica Cultural, n. 10, p. 48-54, 1995.

NAFICY, Hamid. An accented cinema: exilic and diasporic filmmaking. Princenton: Princenton University Press, 2001.

NÚÑEZ, Fabian. O pensamento de Frantz Fanon no cinema latinoamericano. Estudos de Cinema. São Paulo: Annablume. p. 61-67. 2006.

ORTIZ, Renato. Cultura brasileira e identidade nacional. São Paulo: Brasiliense, 1985.

PRYSTHON, Ângela. A Terra em Transe: o cosmopolitismo às avessas do cinema novo. Galáxia. São Paulo: PUC, n. 4, p. 159-175. 2002.

RIDENTI, Marcelo. Artistas e intelectuais no Brasil pós-1960. Tempo Social. Revista de Sociologia da USP, v. 17, n. 1, p. 81-110. 2005. <http://www.scielo.br/pdf/ts/v17n1/ v17n1a03.pdf>

ROCHA, Glauber. Revolução do Cinema Novo. Rio de Janeiro: Alhambra; Embrafilme, 1981.

ROCHA, Glauber. Roteiro do Terceyro Mundo. Rio de Janeiro: Alhambra/Embrafilme, 1985.

ROCHA, Glauber. Cartas ao mundo. São Paulo: Companhia das Letras. 1997.

ROLLEMBERG, Denise. Exílio: entre raízes e radares. Rio de Janeiro: Record, 1999.

SAID, Edward W. Representações do intelectual: as conferências Reith de 1993. São Paulo: Editora Companhia das Letras, 2005.

SHOHAT, Ella; STAM, Robert. Crítica da imagem eurocêntrica. São Paulo: Cosac Naify, 2006.

SPIVAK, Gayatri. Pode o subalterno falar? Belo Horizonte: Editora da UFMG, 2010.

STRECKER, Marcos. Na estrada: o cinema de Walter Salles. São Paulo: Publifolha, 2010 .

SOARES, Paulo Marcondes F. Um cinema à margem. Estudos de Sociologia. v. 15, n. 2, p. 207-227. 2009.

SOLANAS, Fernando; GETINO, Octavio. Hacia un tercer cine - apuntes y experiencias para el desarrollo de un cine de liberación en el tercer mundo. [s.d.]<www.cinefagos. net $/$ index.php?option $=$ com_content $\&$ view $=$ category $\&$ id $=30 \&$ Itemid $=60>$. 
VOLPE, Miriam L. Geografias de exílio: Belo Horizonte, v. 7, p. 45-55, 2003 <www. letras.ufmg.br/poslit/08_publicacoes_pgs/Em\%20Tese\%2007/05-Miriam-Volpe.pdf>.

VOLPE, Miriam L. Geografias de exílio. Juiz de Fora: Editora da UFJF, 2005.

WILLIAMS, Raymond. Marxismo e literatura. Rio de Janeiro: Zahar, 1979.

\section{Filmografia}

TERRA em transe. Direção: Gláuber Rocha. Rio de Janeiro: Mapa Produções Cinematográficas, 1967/2006 [produção]. DVD duplo filme (115 min), p\&b. [Cópia restaurada - Versátil Home Video sob licença da Riofilme Distribuidora].

DEPOIS do Transe. Direção: Paloma Rocha e Joel Pizzini. In: TERRA em transe. Direção: Gláuber Rocha. Rio de Janeiro: Mapa Produções Cinematográficas, 1967/2006 [produção]. DVD duplo filme (115 min), p\&b. [Cópia restaurada - Versátil Home Video sob licença da Riofilme Distribuidora].

TERRA Estrangeira. Direção: Walter Salles e Daniela Thomas. São Paulo: Videofilmes, 1996 [produção executiva Flavio Tambellini]. DVD (100 min.), p\&b.

ROCHA, Glauber. Depoimento. In: Rocha, Paloma e Pizzini, Joel. Depois do Transe.

XAVIER, Ismail. Depoimento. In: Rocha, Paloma e Pizzini, Joel. Depois do Transe.

Data de recebimento: 30 set. 2013

Data de aprovação: 25 nov. 2013

Autor correspondente:

Paulo Marcondes Ferreira Soares

UFPE - Departamento de Sociologia

Avenida da Arquitetura, s/n. CFCH, 12 andar

Cidade Universitária

50740-550 Recife, PE 